\title{
Diagnostic accuracy of ultrasonography and scoring systems: The effects on the negative appendectomy rate and gender
}

\author{
다) Rahman Şenocak, M.D., (1) Şahin Kaymak, M.D.
}

Department of General Surgery, Health Science University Gülhane Training and Research Hospital, Ankara-Turkey

\begin{abstract}
BACKGROUND: Despite the development of clinical, laboratory, and imaging methods, the diagnosis of acute appendicitis is not always easy, and negative appendectomy rates are still high. This study aims to reveal the effects of different scoring systems on the diagnostic accuracy of acute appendicitis and negative appendectomy rates, alone or when evaluated together with ultrasonography.
\end{abstract}

METHODS: In this study, 202 consecutive patients who underwent emergency appendectomy for acute appendicitis were included. Clinical scores of all patients were preoperatively calculated using Ohmann, Raja Isteri Pengiran Anak Saleha Appendicitis (RIPASA), Lintula, Eskelinen, and Alvarado scoring systems. Abdominal ultrasonography (USG) was performed randomly in all cases. The sensitivity and specificity of scoring systems were calculated according to the threshold values. The area under the curve (AUC) was calculated using ROC analysis. In the regression model, histological diagnosis of appendicitis was used as the dependent variable, while scoring systems and USG were preferred as independent variables.

RESULTS: The negative appendectomy rate was $15.8 \%$. In the diagnosis of acute appendicitis, Ohmann was the most predictive for both genders (DOR=24.2, 95\% Cl 6.98-84.44). Similarly, the lowest negative appendectomy rates were obtained with the Ohmann score as $6.9 \%$ in females and $3.4 \%$ in males. When the scores were combined with USG, the rate of diagnostic accuracy for acute appendicitis was not increased. However, when Ohmann and USG were combined, negative appendectomy rates were further reduced for women from $6.9 \%$ to $4 \%$.

CONCLUSION: In addition to being a good diagnostic predictor of acute appendicitis in male and female patients, Ohmann score provides the best negative appendectomy rates. The combination of USG and scoring systems does not increase the diagnostic accuracy of acute appendicitis. However, negative appendectomy rates are significantly reduced when the USG and Ohmann scale are used together in females, while this reduction is minimal in men.

Keywords: Alvarado; Eskelinen; Lintula; negative appendectomy rate; Ohmann; RIPASA; USG.

\section{INTRODUCTION}

Acute appendicitis (AA) is the most common cause of emergency abdominal surgery. To prevent serious complications up to $17-33 \%$ perforation rates, rapid and early diagnosis should be made. ${ }^{[1]}$ Occasionally, the decision of surgical indication in atypical acute appendicitis may be difficult due to the incomplete clinical findings. ${ }^{[2]}$ Therefore, the main objective is to achieve the lowest negative appendectomy rates (NARs), while reducing morbidity and hospital cost without diagnostic delay.

Various scoring systems have been developed to support diagnosis in suspected cases for AA. ${ }^{[3-7]}$ Some of these systems target pediatrics or female populations: ${ }^{[4,5]}$ other systems target the general population. ${ }^{[7]}$ Positive and negative predictive values were reported to differ between the results, ${ }^{[8]}$ and it was suggested that accurate diagnosis rates could be in-

Cite this article as: Şenocak R, Kaymak Ş. Diagnostic accuracy of ultrasonography and scoring systems: The effects on the negative appendectomy rate and gender. Ulus Travma Acil Cerrahi Derg 2020;26:306-313.

Address for correspondence: Şahin Kaymak, M.D.

Sağılık Bilimleri Üniversitesi Gülhane Eğitim ve Araştırma Hastanesi, Genel Cerrahi Kliniği, Ankara, Turkey

Tel: +90 312 - 3045112 E-mail: sahinkaymak@hotmail.com

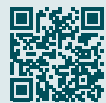

Ulus Travma Acil Cerrahi Derg 2020;26(2):306-313 DOI: 10.14744/tjtes.2019.86717 Submitted: 08.12.2019 Accepted: 31.12.2019 Online: II.03.2020

Copyright 2020 Turkish Association of Trauma and Emergency Surgery 
creased and NARs could be reduced with integration scoring systems and imaging methods. ${ }^{[9,10]}$ However, in the literature, studies on the superiority between appendicitis scoring systems are limited and the results are controversial.

Diagnostic imaging of acute appendicitis has improved in recent years. Although the sensitivity and specificity of computed tomography (CT) in the diagnosis of appendicitis is known to be as high as $94 \%,{ }^{[1]}$ it is not preferred in all routine cases because it contains ionized radiation, increases the cost of routine health, and may delay the emergency appendectomy. Ultrasonography (USG) is still the most widely used diagnostic method in the diagnosis of acute appendicitis in many centers due to its rapid and practical application and its good tolerability by the pediatric population. ${ }^{[I]}$ However, despite these advances in diagnostic methods, to our knowledge, there is no information in the literature that NARs have been reduced to the desired level. ${ }^{[12]}$ Therefore, this study aims to determine the effects of various appendicitis scoring systems on the diagnostic accuracy of AA and NARs, alone or when evaluated together with USG.

\section{MATERIALS AND METHODS}

A total of 202 consecutive patients, who were admitted to the emergency ward of Gülhane Training and Research Hospital in Ankara, Turkey, and were operated on in the general surgery clinic with the diagnosis of acute appendicitis between 0I January 2017 and 31 December 2017, were included in this study. This was a retrospective cross-sectional study. The Ethical Committee of Clinical Research found no ethical problem in carrying out the present study because this study did not involve a prospective evaluation of a new method and only involved research showing standard clinical practices or advancement of practices.

Demographic characteristics, age and gender of the cases were recorded. Physical examinations were performed randomly by five general surgeons from the same clinic, and the clinical parameters of all patients were recorded in a prospective manner using a previously prepared form on admission, according to the RIPASA, ${ }^{[3]}$ Alvarado, ${ }^{[7]}$ Ohmann, ${ }^{[6]}$ Lintula, ${ }^{\left[{ }^{[]}\right.}$ and Eskelinen ${ }^{[4]}$ scoring systems (Table I). Thus scores were preoperatively calculated.

Due to the design of this study, abdominal ultrasonography was performed randomly by four separate radiologists working in the same department. USG examination was performed with a Toshiba Fomio 8 , using the 3.75 and $8 \mathrm{Mhz}$ linear probes. The diagnosis of appendicitis was based on the visualization of the blind-ending tubular structure in the right lower quadrant of the abdomen with a diameter greater than $6 \mathrm{~mm}$, indicating a non-compressible intestinal structure. In this study, patients with a score equal to or above the threshold according to scoring systems, or patients whose diagnosis of acute appendicitis was supported by USG were operated on. Negative appendectomy was defined by postoperative histopathologic examination as no evidence of inflammation in the appendix wall or absence of polymorphonuclear leukocytes.

Data analysis was performed using SPSS version I5.0 (IBM ${ }^{\circledR}$, Chicago, USA). The sensitivity, specificity of RIPASA, Alvarado, Ohmann, Lintula and Eskelinen scoring systems were calculated according to the threshold values reported in the literature. In addition, the area under the curve (AUC) was calculated using ROC analysis. The values with the best sensitivity and specificity were defined by the likelihood ratio. The combination of the score with USG was defined as the presence of positive USG findings in patients whose scoring systems exceeded the threshold. Negative appendectomy rates, sensitivity and specificities of scoring systems were analyzed separately and in combination with USG. Pairwise comparisons of ROC analysis were used to analyze the superiority of scoring systems. Also, binary logistic regression analysis was preferred for comparison of scoring systems. In the regression model, histological appendicitis diagnosis was used as the dependent variable, while scoring systems and USG were preferred as independent variables. Results were expressed as Diagnostic Odds Ratio (DOR) at $95 \%$ Confidence Interval $(95 \% \mathrm{Cl})$. In statistical analysis, the $\mathrm{p}$-value was considered significant below 0.05 .

\section{RESULTS}

The mean age of 202 patients who underwent laparotomy for acute appendicitis was 25.6 \$8.8 years (range between 14-69 years). The majority of patients were male. The male/female ratio was $1 / 0.3$. Mean RIPASA score was $9.8 \pm 2$.I (range between 4.5-15), Ohmann score was 13.5 \pm 2 .I (range between 8-16), Lintula score was $21.5 \pm 5.2$ (range between 4-32). The Eskelinen score was 59.6 \pm 5.7 (range between 44.7-67.7), and the Alvarado score was 7.3 \pm 1.7 (range between 2-10). Acute appendicitis was detected in $79.7 \%$ of the patients by USG. Histological examination revealed acute appendicitis in $84.2 \%$ $(n=170)$ of the patients. The NAR was $15.8 \%(n=32)$. Table 2 shows the sociodemographic characteristics, clinical characteristics, and scores of the patients.

When the thresholds previously reported in the literature were used for the diagnosis of acute appendicitis, Sensitivity of RIPASA, Ohmann, Lintula, Eskelinen, and Alvarado was $83.5 \%, 82.3 \%, 69.4 \%, 76.4 \%$, and $75.8 \%$ (respectively), and specificity was $37.5 \%, 81.2 \%, 50 \%, 65.6 \%, 65.6 \%$ (respectively). NARs were $12.3 \%, 4.1 \%$, $11.9 \%, 7.8 \%, 7.9 \%$ respectively. In all scoring systems, NARs tended to be lower in male patients than in female patients. The lowest NARs were obtained with Ohmann scoring in both female $(6.9 \%)$ and male $(3.4 \%)$ patients.

In the logistic regression model, the most predictive scale for acute appendicitis was Ohmann $(D O R=24.2,95 \% \mathrm{Cl}$ 
6.98-84.44), and the second was Alvarado (DOR=2.5, 95\% Cl 0.85-7.88) (Table 3). Similarly, when divided by gender, the most predictive method of diagnosis for acute appendicitis in females (DOR=60.2, 95\% Cl 2.84-1274) and in males (DOR=30.5, 95\% Cl 6.54-142.75) was Ohmann. Also, USG's sensitivity was $91.9 \%$, and specificity was $23 \%$, and its effectiveness in the diagnosis of acute appendicitis was observed to be low $(\mathrm{DOR}=1.7,95 \% \mathrm{Cl} 0.55-5.44)$.
Although all scoring systems for acute appendicitis were determinative in ROC analysis, the highest AUC (accuracy in predicting acute appendicitis) value was observed in Ohmann scoring (AUC=0.8I8, $\mathrm{p}<0.00 \mathrm{I}, 95 \% \mathrm{Cl}=0.758-0.869$ ) (Table 4, Fig. I). In the comparison of the pairwise ROC curves for the diagnosis of acute appendicitis, the Ohmann scale was more predictive than Lintula $(p<0.001)$, Eskelinen $(p=0.012)$, RIPASA $(p<0.00 \mathrm{I})$, and Alvarado $(p=0.040)$.

Table I. RIPASA, Ohmann, Lintula, Eskelinen and Alvarado evaluation tables

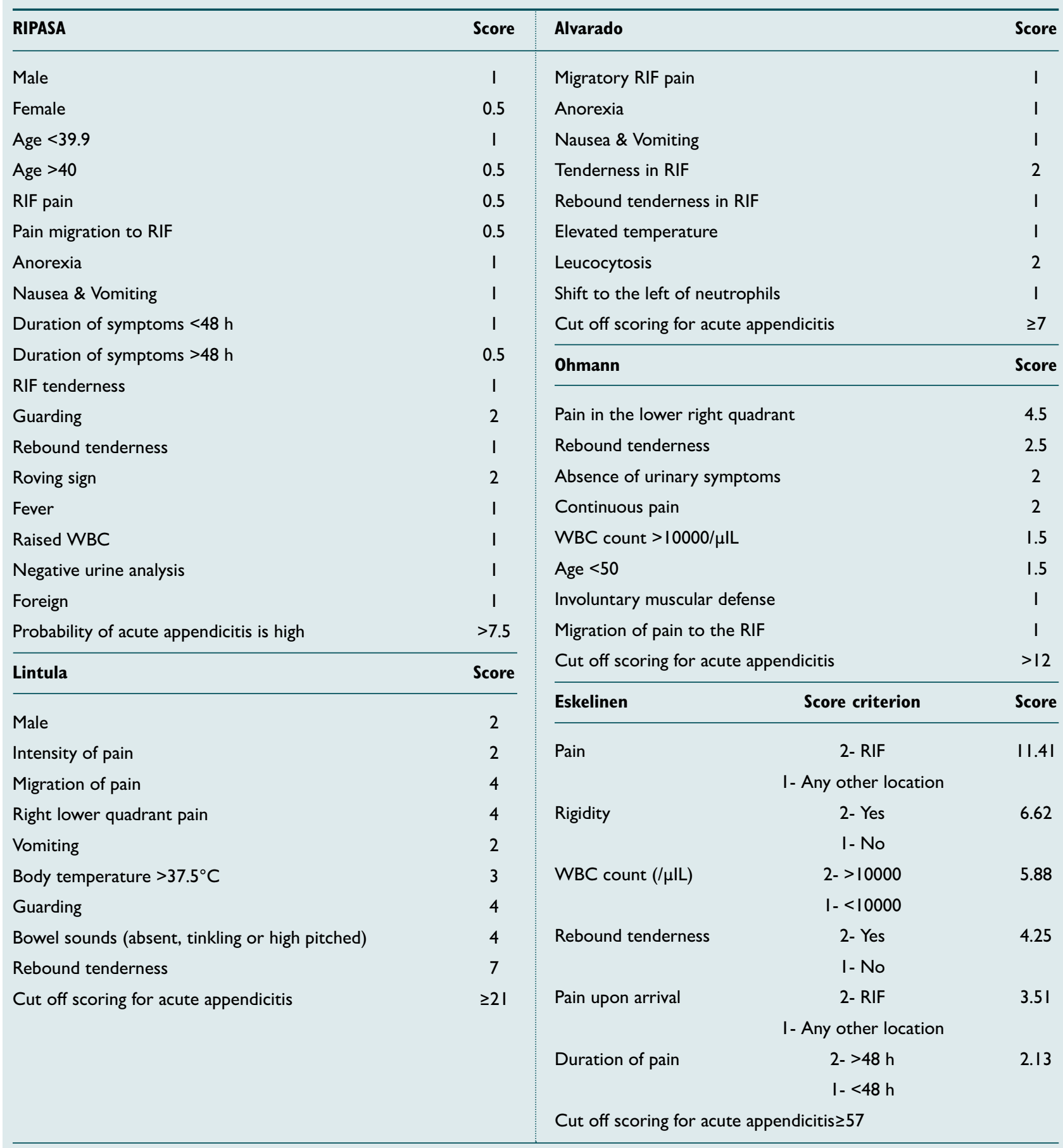

RIPASA: Raja Isteri Pengiran Anak Saleha Appendicitis; WBC: White blood cell; RIF: Right lliac Fossa; NRIC: National record of identity card; 
By combining USG with scoring systems, the highest predictivity was obtained by Ohmann+USG combination. However, for acute appendicitis, the USG combination

Table 2. Socio-demographic and clinical characteristics of the patients

\begin{tabular}{|c|c|c|c|}
\hline & $\mathbf{n}$ & $\%$ & Mean $\pm S D$ \\
\hline Age & & & $25.6 \pm 8.8$ \\
\hline \multicolumn{4}{|l|}{ Gender } \\
\hline Female & 50 & 24.8 & \\
\hline Male & 152 & 75.2 & \\
\hline RIPASA & & & $9.8 \pm 2.1$ \\
\hline Ohmann & & & $13.5 \pm 2.1$ \\
\hline Lintula & & & $21.5 \pm 5.2$ \\
\hline Eskelinen & & & $59.6 \pm 5.7$ \\
\hline Alvarado & & & $7.3 \pm 1.7$ \\
\hline \multicolumn{4}{|c|}{ Abdominal ultrasonography } \\
\hline Positive (+) & 161 & 79.7 & \\
\hline Negative (-) & 41 & 20.3 & \\
\hline White blood cell count & & & $13.5 \pm 3.9$ \\
\hline \multicolumn{4}{|l|}{ Pathology report } \\
\hline Positive (+) & 170 & 84.2 & \\
\hline Negative (-) & 32 & 15.8 & \\
\hline
\end{tabular}

RIPASA: Raja Isteri Pengiran Anak Saleha Appendicitis; SD: Standard deviation. with Ohmann (DOR $=17.5,95 \% \mathrm{Cl} 4.35-70.75)$ was found to have lower predictivity compared to the Ohmann scale alone $(D O R=24.2$, 95\% Cl 6.98-84.44) (Table 5). On the other hand, the lowest NARs (4\%) were achieved in women when Ohmann was combined with USG. In ROC analysis, the highest AUC value was observed in Ohmann scoring ( $A \cup C=0.748, \quad \mathrm{p}<0.00 \mathrm{I}, 95 \% \mathrm{Cl}=0.683-0.807)$ (Table 6).

When the ROC analyses obtained with using scoring systems alone or in combination with USG were compared, the AUC for acute appendicitis was decreased with the USG combination with the scoring systems, but no statistical difference was in found two analyses.

Table 4. ROC analysis of scoring systems in the diagnosis of the AA

\begin{tabular}{lcccc}
\hline & AUC & SD & p & $\% 95$ Cl \\
\hline RIPASA & 0.605 & 0.046 & 0.021 & $0.534-0.673$ \\
Ohmann & 0.818 & 0.038 & $<0.001$ & $0.758-0.869$ \\
Lintula & 0.597 & 0.048 & 0.044 & $0.526-0.665$ \\
Eskelinen & 0.710 & 0.046 & $<0.001$ & $0.643-0.772$ \\
Alvarado & 0.708 & 0.046 & $<0.001$ & $0.640-0.769$ \\
\hline
\end{tabular}

AUC: Area under the curve; SD: Standard deviation; $\mathrm{Cl}$ : Confidence interval; ROC: Receiver Operating Characteristic; AA: Acute appendicitis; RIPASA: Raja Isteri Pengiran Anak Saleha Appendicitis.

Table 3. Diagnostic performance parameters of scoring systems and ultrasonography in the diagnosis of the acute appendicitis

\begin{tabular}{|c|c|c|c|c|c|c|c|}
\hline & Sensitivity & Specificity & PPV & NPV & DOR & $\% 95 \mathrm{Cl}$ & NAR \\
\hline RIPASA & 83.5 & 37.5 & 87.6 & 30 & 0.4 & $0.12-1.42$ & 12.3 \\
\hline Female & 64.8 & 46.1 & 77.4 & 31.5 & $<0.1$ & $0-1.15$ & 22.6 \\
\hline Male & 88.7 & 31.5 & 90 & 28.6 & 0.6 & $0.14-3.17$ & 9.9 \\
\hline Ohmann & 82.3 & 81.2 & 95.8 & 46.4 & 24.2 & $6.98-84.44$ & 4.1 \\
\hline Female & 72.9 & 84.6 & 93.1 & 52.3 & 60.2 & $2.84-1274$ & 6.9 \\
\hline Male & 85 & 79 & 96.6 & 42.9 & 30.5 & $6.54-142.75$ & 3.4 \\
\hline Lintula & 69.4 & 50 & 88 & 23.5 & 0.4 & $0.10-1.47$ & 11.9 \\
\hline Female & 56.7 & 61.5 & 80.7 & 33.3 & I.I & $0.11-11.66$ & 19.2 \\
\hline Male & 72.9 & 42.1 & 89.8 & 18.1 & 0.3 & $0-1.7 \mid$ & 10.2 \\
\hline Eskelinen & 76.4 & 65.6 & 92.2 & 34.4 & 2.1 & $0.53-8.26$ & 7.8 \\
\hline Female & 64.8 & 84.6 & 92.3 & 45.8 & 7.4 & $0.45-122.3$ & 7.7 \\
\hline Male & 79.7 & 52.6 & 92.1 & 27 & 0.9 & $0.16-5.77$ & 7.8 \\
\hline Alvarado & 75.8 & 65.6 & 92.1 & 33.8 & 2.5 & $0.85-7.88$ & 7.9 \\
\hline Female & 78.3 & 69.2 & 87.8 & 52.9 & 3.2 & $0.37-27.5$ & 12.1 \\
\hline Male & 75.1 & 63.1 & 93.4 & 26.6 & 2.6 & $0.63-11.03$ & 6.5 \\
\hline Ultrasonography & 81.1 & 28.1 & 85.7 & 21.9 & 1.7 & $0.55-5.44$ & 14.3 \\
\hline Female & 91.9 & 23 & 77.2 & 50 & II.I & $0.42-291.64$ & 22.7 \\
\hline Male & 78.2 & 31.5 & 88.8 & 17.1 & 1.5 & $0.42-5.83$ & II.I \\
\hline
\end{tabular}

PPV: Positive predictive value; NPV: Negative predictive value; DOR: Diagnostic Odds Ratio; Cl: Confidence interval; NAR: Negative appendectomy ratio. 
Table 5. Diagnostic performance parameters of scoring systems and USG combination in the diagnosis of the acute appendicitis

\begin{tabular}{|c|c|c|c|c|c|c|c|}
\hline & Sensitivity & Specificity & PPV & NPV & DOR & $\% 95 \mathrm{Cl}$ & NAR \\
\hline USG+Ripasa >7.5 & 65.9 & 53.1 & 88.1 & 22.6 & 0.2 & $0-0.83$ & 11.8 \\
\hline Female & 59.5 & 61.5 & 81.5 & 34.8 & 0 & $0-1.48$ & 18.5 \\
\hline Male & 67.7 & 47.4 & 90 & 17.3 & 0.2 & $0-1.59$ & 10 \\
\hline USG+Ohmann >12 & 65.2 & 84.3 & 95.6 & 31.4 & 17.5 & $4.35-70.75$ & 4.3 \\
\hline Female & 64.9 & 92.3 & 96 & 48 & 34.7 & $1.84-655.21$ & 4.0 \\
\hline Male & 65.4 & 79 & 95.7 & 24.6 & 17.2 & $3-97.92$ & 4.4 \\
\hline USG+Lintula $\geq 21$ & 55.8 & 68.7 & 90.4 & 22.6 & 0.5 & $0.12-2.63$ & 9.5 \\
\hline Female & 54.1 & 84.6 & 90.9 & 39.2 & 1.7 & $0.16-19.91$ & 9.1 \\
\hline Male & 56.4 & 57.9 & 90.4 & 15.9 & 0.2 & $0-2.50$ & 9.6 \\
\hline USG+Eskelinen $\geq 57$ & 61.7 & 71.8 & 92.1 & 26.1 & 1.6 & $0.33-8.60$ & 7.9 \\
\hline Female & 59.5 & 84.6 & 91.7 & 42.3 & 4.1 & $0.26-66.88$ & 8.3 \\
\hline Male & 62.4 & 63.1 & 92.2 & 19.3 & 1.2 & $0.1-12.21$ & 7.8 \\
\hline USG+Alvarado $\geq 7$ & 61.1 & 71.8 & 92 & 25.8 & 2.5 & $0.74-8.97$ & 8 \\
\hline Female & 70.2 & 69.2 & 86.7 & 45 & 2.5 & $0.34-18.13$ & 13.3 \\
\hline Male & 58.6 & 73.7 & 94 & 20.2 & 3.7 & $0.78-18.46$ & 6.0 \\
\hline
\end{tabular}

USG: Ultrasonography; PPV: Positive predictive value; NPV: Negative predictive value; DOR: Diagnostic Odds Ratio; Cl: Confidence interval; NAR: Negative appendectomy ratio.

Table 6. ROC analysis of scoring systems and USG combination in the diagnosis of the AA

\begin{tabular}{lcccc}
\hline & AUC & SD & p & $\% 95 \mathbf{C l}$ \\
\hline RIPASA+USG & 0.595 & 0.048 & 0.049 & $0.524-0.663$ \\
Ohmann+USG & 0.748 & 0.037 & $<0.001$ & $0.683-0.807$ \\
Lintula+USG & 0.623 & 0.046 & 0.007 & $0.552-0.690$ \\
Eskelinen+USG & 0.668 & 0.044 & 0.001 & $0.599-0.733$ \\
Alvarado+USG & 0.665 & 0.044 & 0.001 & $0.596-0.730$ \\
\hline
\end{tabular}

AUC: Area under the curve; SD: Standard deviation; Cl: Confidence interval; ROC: Receiver Operating Characteristic; AA: Acute appendicitis; RIPASA: Raja Isteri Pengiran Anak Saleha Appendicitis; USG: Ultrasonography;

\section{DISCUSSION}

Despite the development of clinical and diagnostic methods in acute appendicitis, difficulties in making the correct diagnosis remain. While morbidity rates due to diagnostic delays increase, NARs are still seen between $15-23 \% .{ }^{[13]}$ In this study, the NARs were $15.8 \%$ comparable with other studies. Various non-invasive and cost-effective scoring systems have been developed to minimize morbidity and negative appendectomy. In this study, the sensitivity and specificity of the Ohmann scoring system were highest among all scoring systems and it was found to be more predictive in the diagnosis of acute appendicitis in the regression model compared to other scoring systems. In all scoring systems, the rate of a negative appendectomy was lower in male patients than in female patients. When scoring systems were combined with

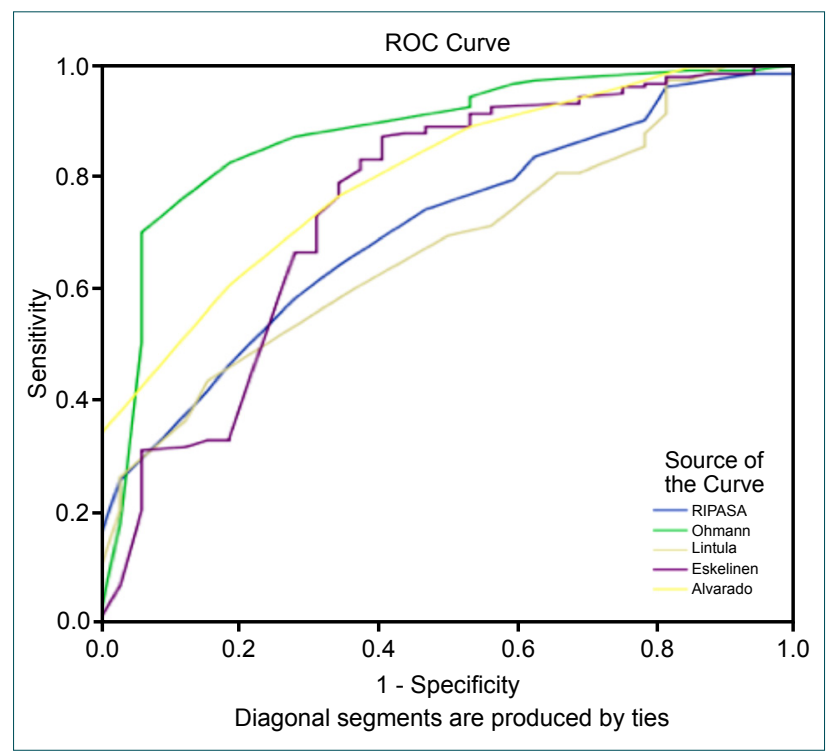

Figure 1. ROC curves of scoring systems.

USG, it was seen that the diagnostic accuracy of acute appendicitis and DOR were not increased, whereas when Ohmann scoring system was combined with USG, the lowest NAR was obtained, especially in women.

It is stated in some of the literature that the Ohmann scoring system is superior to other scoring systems in the diagnosis of acute appendicitis. In the study of Rastović et al. ${ }^{[14]}$ comparing Modified Alvarado, Ohmann, and Eskelinen scoring systems in the diagnosis of acute appendicitis, it was stated that the scoring system with the best sensitivity and speci- 
ficity was Ohmann. Similarly, Erdem et al. ${ }^{[2]}$ reported that among Alvarado, Eskelinen, Ohmann, and RIPASA, the best scoring system was the Ohmann scoring system with $83.1 \%$ sensitivity and $80.6 \%$ specificity. Zielke et al. ${ }^{[15]}$ reported that the sensitivity and specificity of the Ohmann scoring system were $63 \%$ and $93 \%$ in a study of 2359 patients with acute appendicitis. In this study, the sensitivity and specificity of the Ohmann scoring system were $82.3 \%$ and $81.2 \%$, respectively. In addition, the highest AUC was observed via the Ohmann scoring system, although Lintula and Ripasa were weak, and all other scoring systems have strong diagnostic accuracy for acute appendicitis. Although some prospective studies have shown that scoring systems may be insufficient as a diagnostic test alone, it has been reported that good results can be obtained by combining clinical evaluation with either USG or Ohmann scoring. ${ }^{[15]}$

Although USG has been shown to have more than $70 \%$ sensitivity and specificity in the diagnosis of acute appendicitis, and it has been shown to have high diagnostic accuracy in acute appendicitis, the method depends largely on the user's experience and knowledge. ${ }^{[16-18]}$ In the study conducted by Hosseini et al., ${ }^{[19]}$ the sensitivity and specificity of USG were reported as $37.1 \%$ and $87.2 \%$, respectively, in tertiary health care centers. Due to its low negative predictive value (II.7\%), USG was recommended for differential diagnosis and complicated cases of appendicitis rather than routine use. In a review by Pinto et al.,[20] it was stated that USG had highly variable sensitivity and specificity. In this study, sensitivity, specificity and Negative Predictive Value (NPV) of USG were $81.1 \%, 28.1 \%$, and $21.9 \%$, respectively. In addition, the scoring systems had similar sensitivity to USG and higher specificity than USG, and the combination of scoring systems with USG did not increase the diagnostic accuracy of acute appendicitis. These results were consistent with the recommendations in the literature stating that USG needs to be used in differential diagnosis or suspicious cases rather than routinely.

It is demonstrated in a study that acute appendicitis might be overlooked in $33 \%$ of premenopausal women, the NARs were $45 \%$ and gynecological causes constituted more than half of the cases in the premenopausal period. Additionally, the sensitivity of diagnosis of acute appendicitis by USG was $65 \%$, with a specificity of $41 \%$, which was lower than reported. USG had a $65 \%$ sensitivity and $41 \%$ specificity. Althoubaity et al. ${ }^{[2]]}$ concluded that negative appendectomy rates did not decrease with USG and could be decreased to a minimum of $8.3 \%$ by CT. In this study, the higher detection rate of negative appendectomy (22\%) using only USG in female patients indicated that USG and scoring systems were more important in females. On the other hand, it was reported that scoring systems were also affected by age group, gender, and geographical population. ${ }^{[2]}$ In our study, the integration of USG with the scoring systems did not change the DOR of Alvarado and Lintula, regardless of gender, but decreased the others. Similarly, it did not significantly reduce the NARs. In other words, the combination of the scoring systems with USG did not contribute positively to diagnostic accuracy and NARs. However, when analyzed by gender, NARs decreased in Lintula, Ripasa, and Ohmann scoring systems in female patients, yet did not change significantly in male patients. In conclusion, combining Ohmann, Lintula, and Ripasa scoring systems with USG can reduce NARs down to $4 \%$ in female patients. Regression analysis showed that the combination of scoring systems with USG reduced the AUC value in the diagnosis of acute appendicitis and the lowest NAR was obtained in female patients who were evaluated by a combination of USG and Ohmann. Similarly, Horzić et al. ${ }^{[23]}$ stated that NARs were reduced by using Ohmann and Alvarado scores in female patients, while Althoubaity ${ }^{[2]}$ stated that the Alvarado score in women had $89 \%$ sensitivity and $40 \%$ specificity and could have an effect on reducing NAR in female patients.

It has been reported in previous studies that scoring systems reduce NARs or increase diagnostic accuracy. These scoring systems include Alvarado ${ }^{[10,24]}$ RIPASA, ${ }^{[25]}$ Ohmann, ${ }^{[14]}$ Eskelinen, ${ }^{[26]}$ Lintula $^{[27]}$ and Adult Appendicitis Score. ${ }^{[28]}$ However, the number of studies in which these systems were evaluated on a large scale and with imaging methods was quite limited. Mariadason et al. ${ }^{[9]}$ found that in $76.1 \%$ of patients with positive Alvarado score $1.9 \%$ NARs were obtained, in $82.4 \%$ of patients in appendicitis detected with CT I.3\% NARs were obtained, especially male patients had minimal benefit from $C T$, and that CT would not be needed for many patients. Genzor et al. ${ }^{[10]}$ reported that NAR rates decreased from $5.2 \%$ to $4.3 \%$ when Alvarado score above 5 and USG were evaluated together. Jha et al. ${ }^{[29]}$ suggested that performing CT after USG can only benefit $3.1 \%$ of false-negative USG patients. Therefore, the patients can be evaluated with scoring systems without a CT scan. In this study, it was seen that more accurate results were obtained with Ohmann scoring rather than Alvarado scoring which is preferred more frequently in surgical practice, NARs were lowered, and for female patients, the lowest NAR was obtained when Ohmann was combined with USG.

Our study had some limitations. First, the effects of CT imaging could not be evaluated, but it was aimed to analyze the effects of USG which were more accessible and more applicable. Second, scoring systems were evaluated only in patients who underwent the appendectomy. Therefore, the sensitivity and specificity of scoring systems in the diagnosis of acute appendicitis may be overestimated.

In conclusion, the use of scoring systems in the diagnosis of acute appendicitis not only increases the accuracy of the diagnosis but also reduces the NARs. Among the scoring systems in which the results differ geographically, Ohmann scoring gave the best results considering the NARs and DOR in the patients. To decrease NAR, especially in female patients, USG is recommended to be evaluated together with scoring sys- 
tems. With the quick and easy application of Ohmann scoring, diagnosis of acute appendicitis can be supported in cases where CT or USG facilities are limited, the need for tests that contains ionizing radiation, such as $\mathrm{CT}$ can be reduced, and unnecessary health costs, can be prevented by facilitating the early diagnosis of acute appendicitis.

\section{Ethics Committee Approval: Retrospective study.}

Peer-review: Internally peer-reviewed.

Authorship Contributions: Concept: R.Ş., Ş.K.; Design: R.Ş., Ş.K.; Supervision: R.Ş., Ş.K.; Fundings: R.Ş., Ş.K.; Materials: R.Ş., Ş.K.; Data: R.Ş., Ş.K.; Analysis: R.Ş., Ş.K.; Literature search: R.Ş., Ş.K.; Writing: R.Ş., Ş.K.; Critical revision: R.Ş., Ş.K.

Conflict of Interest: None declared.

Financial Disclosure: The authors declared that this study has received no financial support.

\section{REFERENCES}

1. Toprak H, Kilincaslan H, Ahmad IC, Yildiz S, Bilgin M, Sharifov R, et al. Integration of ultrasound findings with Alvarado score in children with suspected appendicitis. Pediatr Int 2014;56:95-9. [CrossRef]

2. Erdem H, Çetinkünar S, Daş K, Reyhan E, Değer C, Aziret M, et al. Alvarado, Eskelinen, Ohhmann and Raja Isteri Pengiran Anak Saleha Appendicitis scores for diagnosis of acute appendicitis. World J Gastroenterol 2013;19:9057-62. [CrossRef]

3. Chong CF, Adi MI, Thien A, Suyoi A, Mackie AJ, Tin AS, et al. Development of the RIPASA score: a new appendicitis scoring system for the diagnosis of acute appendicitis. Singapore Med J 2010;51:220-5.

4. Eskelinen M, Ikonen J, Lipponen P. Sex-specific diagnostic scores for acute appendicitis. Scand J Gastroenterol 1994;29:59-66. [CrossRef]

5. Lintula H, Kokki H, Pulkkinen J, Kettunen R, Gröhn O, Eskelinen M. Diagnostic score in acute appendicitis. Validation of a diagnostic score (Lintula score) for adults with suspected appendicitis. Langenbecks Arch Surg 2010;395:495-500. [CrossRef]

6. Ohmann C, Franke C, Yang Q, Margulies M, Chan M, van Elk PJ, et al. Diagnosescore für akute Appendicitis [Diagnostic score for acute appendicitis]. Chirurg 1995;66:135-41.

7. Alvarado A. A practical score for the early diagnosis of acute appendicitis. Ann Emerg Med 1986;15:557-64. [CrossRef]

8. Xingye W, Yuqiang L, Rong W, Hongyu Z. Evaluation of Diagnostic Scores for Acute Appendicitis. J Coll Physicians Surg Pak 2018;28:1104. [CrossRef]

9. Mariadason JG, Wang WN, Wallack MK, Belmonte A, Matari H. Negative appendicectomy rate as a quality metric in the management of appendicitis: impact of computed tomography, Alvarado score and the definition of negative appendicectomy. Ann R Coll Surg Engl 2012;94:395-401.

10. Genzor Ríos SJ, Rodríguez Artigas JM, Giménez Maurel T, Vallejo Bernad C, Aguirre Prat N, Miguelena Bobadilla JM. Ultrasonography and the Alvarado score in the diagnosis of acute appendicitis: impact on the negative appendectomy rate. [Article in Spanish]. Emergencias 2016;28:396-9.

11. Doria AS, Moineddin R, Kellenberger CJ, Epelman M, Beyene J, Schuh S, et al. US or CT for Diagnosis of Appendicitis in Children and Adults? A Meta-Analysis. Radiology 2006;241:83-94. [CrossRef]
12. Ma KW, Chia NH, Yeung HW, Cheung MT. If not appendicitis, then what else can it be? A retrospective review of 1492 appendectomies. Hong Kong Med J 2010;16:12-7.

13. Sezer TO, Gulece B, Zalluhoglu N, Gorgun M, Dogan S. Diagnostic value of ultrasonography in appendicitis. Adv Clin Exp Med 2012;21:633-6.

14. Rastović P, Trninić Z, Galić G, Brekalo Z, Lesko J, Pavlović M. Accuracy of Modified Alvarado Score, Eskelinen Score and Ohmann Score in Diagnosing Acute Appendicitis. Psychiatr Danub 2017;29:134-41.

15. Zielke A, Sitter H, Rampp T, Schäfer E, Möbius E, Lorenz W, et al. Can diagnostic scoring systems help decision making in primary care of patients with suspected acute appendicitis?. [Article in German]. Dtsch Med Wochenschr 1999;124:545-50. [CrossRef]

16. Bhangu A, Søreide K, Di Saverio S, Assarsson JH, Drake FT. Acute appendicitis: modern understanding of pathogenesis, diagnosis, and management [published correction appears in Lancet 2017;390:1736.

17. Ahmai Nejad M, Saki M. Study of sonography sensitivity and specificity to the diagnosis of acute appendicitis in suspected patients referred to Khorramabad Ashayer hospital. Sci Mag Yafte 2012;13:23-7.

18. Russo A, Cappabianca S, Iaselli F, Reginelli A, D’Andrea A, Mazzei G, et al. Acute abdominal pain in childhood and adolescence: Assessing the impact of sonography on diagnosis and treatment. J Ultrasound 2013;16:201-7. [CrossRef]

19. Hosseini A, Omidian J, Nazarzadeh R. Investigating Diagnostic Value of Ultrasonography in Acute Appendicitis. Adv Biomed Res 2018;7:113

20. Pinto F, Pinto A, Russo A, Coppolino F, Bracale R, Fonio P, et al. Accuracy of ultrasonography in the diagnosis of acute appendicitis in adult patients: review of the literature. Crit Ultrasound J 2013;5 Suppl 1:S2.

21. Althoubaity FK. Suspected acute appendicitis in female patients. Trends in diagnosis in emergency department in a University Hospital in Western region of Saudi Arabia. Saudi Med J 2006;27:1667-73.

22. Ohle R, O'Reilly F, O'Brien KK, Fahey T, Dimitrov BD. The Alvarado score for predicting acute appendicitis: a systematic review. BMC Med 2011;9:139. [CrossRef]

23. Horzić M, Salamon A, Kopljar M, Skupnjak M, Cupurdija K, Vanjak D. Analysis of scores in diagnosis of acute appendicitis in women. Coll Antropol 2005;29:133-8.

24. Kamran H, Naveed D, Asad S, Hameed M, Khan U. Evaluation of modified Alvarado score for frequency of negative appendicectomies. J Ayub Med Coll Abbottabad 2010;22:46-9.

25. Chae MS, Hong CK, Ha YR, Chae MK, Kim YS, Shin TY, et al. Can clinical scoring systems improve the diagnostic accuracy in patients with suspected adult appendicitis and equivocal preoperative computed tomography findings? Clin Exp Emerg Med 2017;4:214-21. [CrossRef]

26. Sitter H, Hoffmann S, Hassan I, Zielke A. Diagnostic score in appendicitis. Validation of a diagnostic score (Eskelinen score) in patients in whom acute appendicitis is suspected. Langenbecks Arch Surg 2004;389:2138. [CrossRef]

27. Yoldas O, Karaca T, Tez M. External validation of Lintula score in Turkish acute appendicitis patients. Int J Surg 2012;10:25-7. [CrossRef]

28. Sammalkorpi HE, Mentula P, Savolainen H, Leppäniemi A. The Introduction of Adult Appendicitis Score Reduced Negative Appendectomy Rate. Scand J Surg 2017;106:196-201. [CrossRef]

29. Jha P, Espinoza N, Webb E, Kohli M, Poder L, Morgan T. Single institutional experience with initial ultrasound followed by computed tomography or magnetic resonance imaging for acute appendicitis in adults. Abdom Radiol (NY) 2019;44:2357-65. [CrossRef] 
ORİIINAL ÇALIŞMA - ÖZET

\section{Skorlama sistemleri ve ultrasonografinin tanısal doğruluğunun negatif apandektomi oranı ve cinsiyet üzerine etkisi \\ Dr. Rahman Şenocak, Dr. Şahin Kaymak}

Sağlık Bilimleri Üniversitesi, Gülhane Eğitim ve Araştırma Hastanesi, Genel Cerrahi Anabilim Dalı, Ankara

AMAÇ: Klinik, laboratuvar ve görüntüleme yöntemlerinin gelişmesine rağmen akut apandisit tanısı her zaman kolay olmamakta ve negatif apendektomi oranları hala yüksek seyretmektedir. Bu çalışmada amaç skorlama sistemlerinin kendi başına ve ultrasonografi (USG) ile beraber değerlendiğinde, doğru tanı oranlarına (DOR: Diagnostic Odds Ratio) ve negatif apendektomi oranlarına etkilerinin ortaya konulması amaçlandı.

GEREÇ VE YÖNTEM: Çalışmamıza akut apandisit tanısıyla ameliyat edilen ardışık 202 hasta ileriye yönelik olarak dahil edildi. Tüm hastaların Ohmann, Raja Isteri Pengiran Anak Saleha appendicitis (RIPASA), Lintula, Eskelinen ve Alvarado skorlama sistemleri kullanılarak ameliyat öncesi skorları hesaplandı. Olguların tümüne abdominal ultrasonografi randomize olarak uygulandı. Skorlama sistemlerinin sensitivitesi ve spesifitesi eşik değerlerine göre hesaplanmıştır. Eğri altındaki alan (AUC), ROC analizi ile hesaplanmıştır. Regresyon modelinde bağımlı değişken olarak apandisit histolojik tanısı kullanılırken, bağımsız değişkenler olarak skorlama sistemleri ve USG tercih edildi.

BULGULAR: Negatif apendektomi oranı \% I5.8'di. Akut apandisit tanısında her iki cinsiyet için de en belirleyici yöntemin Ohmann olduğu görüldü (Diagnostic Odds Ratio $(D O R)=24.2$, \%95 GA 6.98-84.44). Benzer şekilde en düşük negatif apandektomi oranları kadınlarda \%6.9, erkeklerde \%3.4 ile Ohmann ölçeğiyle elde edildi. Ölçekler, USG ile kombine edildiğinde, akut apandisit belirleyiciliğinde artış olmadığı görüldü. Bununla birlikte kadınlarda Ohmann ile USG kombine edildiğinde negatif apandektomi oranlarının daha da düştüğü görüldü (\%6.9 ve \%4).

TARTIŞMA: Ohmann skorlaması kadın ve erkek hastalarda akut apandisit için iyi bir belirleyici olmasının yanı sıra, en iyi negatif apendektomi oranlarını sağlamaktadır. USG ile skorlama sistemlerinin kombinasyonu akut apandisit tanı değerini arttırmamaktadır, ancak kadınlarda USG ile Ohmann ölçeği birlikte kullanıldığında negatif apandektomi oranları oldukça düşmekteyken, erkeklerde bu fayda minimumdur.

Anahtar sözcükler: Alvarado; Eskelinen; Lintula; negatif apendektomi oranı; Ohmann; RIPASA; USG.

Ulus Travma Acil Cerrahi Derg 2020;26(2):306-3।3 doi: 10.14744/tjtes.2019.867I7 